\title{
Influence of Soil Physical Properties and Terrain Relief on Actual Evapotranspiration in the Catchment with Prevailing Arable Land Determined by Energy Balance and Bowen Ratio
}

\author{
Renata Duffková
}

Additional information is available at the end of the chapter

http://dx.doi.org/10.5772/52810

\section{Introduction}

Actual evapotranspiration rate (ETa) represents a key element of landscape water balance. It plays an active role in the biomass production, establishes the cooling capacity of the region and, depending on soil properties, contributes to runoff formation in the catchment [1-3]. The rate of the process is determined by the gradient of water potential between soil, vegetation, and atmosphere and the prevailing aerodynamic and surface resistances. It integrates the effects of meteorological parameters (precipitation, radiation energy, water saturation deficit and wind speed), soil water content, soil hydraulic properties, vegetation density, height and roughness and the depth of the root system [4-8] on both the spatial and the temporal bases.

Physical properties of soils have a significant influence on their water regime and should be considered when selecting suitable agricultural crops for particular sites, taking into account the crop productivity and its water requirements. The impact of the soil on ETa depends upon the properties of its pore space, which are determined primarily by its grain size distribution and structure. Clay (fine-textured) soils tend to show higher porosity [8-9], higher soil water storage and ETa, but, on the other hand, lower hydraulic conductivity and subsurface runoff [2], compared to sandy (coarse-textured) soils. The highest available moisture-holding capacity is displayed by loamy soils, which, though possessing a somewhat lower field water capacity than the clay soils, exhibit a significantly lower wilting point than the latter. The movement of water in the soil can be extensively altered by the preferential (e.g., macropore) flow, which is 100 to 400 fold faster than water flow in the soil matrix [10], depending on rainfall and snowmelt patterns and, if applied, on irrigation management. 
Physical properties of soils influence the selection of suitable agricultural crops with respect to their water consumption and their productivity. For example in [11] was showed that soil types with higher moisture-holding capacity are better suited to crops, such as corn, that are more sensitive to atmospheric drought than to less sensitive crops, such as wheat.

The spatial distribution of soil types and textures, and thus of the soil water storage, is determined by geology, terrain relief, climate and biotic factors. From a hydrogeologic viewpoint, the catchment can be divided into recharge zones, where precipitation infiltrates and then recharges the groundwater store, and discharge zones, where groundwater approaches the land surface or a surface water body [5]. The recharge zones are mainly located in the highest areas of the catchment, close to the catchment divide, peaks and ridges. The soils of these zones are typically shallow and stony, with high sand content and high infiltration capacity. The coarse-textured soils of the recharge zones are, with respect to groundwater resources, well suited to growing grass, which, beside water quality benefits, increases their field capacity and results in virtually complete infiltration of precipitation, including rainstorms [12-16]. The discharge zones can be found in the lowest parts of the slopes and along surface streams and lakes and are prone to surface waterlogging. The dominant soils in the discharge zones are generally deep, with higher clay content and a lower capacity for infiltration. A connection between the recharge zones and the discharge zones is provided by transient zones, where precipitation is mostly transformed to surface runoff and groundwater flows downslope in a quasi-steady way $[12,17]$. The transient zones are located mainly in the middle sections of slopes. Groundwater in natural catchments flows from the recharge zones to the discharge zones. Actual spatial distribution of these zones depends on local geologic and geomorphologic conditions [18, 19].

\section{The concept of the problem studied}

The topic of the chapter is dealing with the influence of physical soil properties in the recharge, transient, and discharge zones on ETa in a cultivated catchment, where different crops are grown and some fields are tile-drained, in different periods and vegetation development phases. In addition to these comprehensive factors of the habitat, the results of ETa research are also connected with the method used (Bowen ratio method) which is dependent on air temperature and humidity coming over extensive plant cover from prevailing wind direction.

\section{Description of the catchment and weather stations}

The study was conducted in the experimental catchment Dehtáře, situated in the south-west Bohemo-Moravian Highland (Czech Republic), in the years 2004, 2006 and 2009. The outflow point of the catchment lies at $49^{\circ} 28^{\prime} \mathrm{N}-15^{\circ} 12^{\prime} \mathrm{E}$.

The catchment Dehtáře (Fig. 1) has an area of 59.6 ha, with tile drained areas occupying 19 ha $(\sim 32 \%)$. The catchment area is mainly agricultural land $(89.3 \%)$. Minor forested areas (3.3\%) lie 
at its north-western and northern borders. Grassland (20.3\%) covers the southern part of the catchment, as well as the adjacent lowest lying south-western area, which is tile-drained. The remaining area $(69 \%)$ is arable land, which is exploited mainly for cereals production. The catchment geomorphology belongs to the erosion-accumulation relief type [20]. The altitude ranges between 497.0 and $549.8 \mathrm{~m}$. According to Quitt [21], the local climate is classified as moderately warm. According to Köppen [21], it belongs to the temperate broadleaf deciduous forest $(\mathrm{Cfb})$ zone. The average annual total precipitation is $660 \mathrm{~mm}$ and the average air temperature is $7.0^{\circ} \mathrm{C}$.

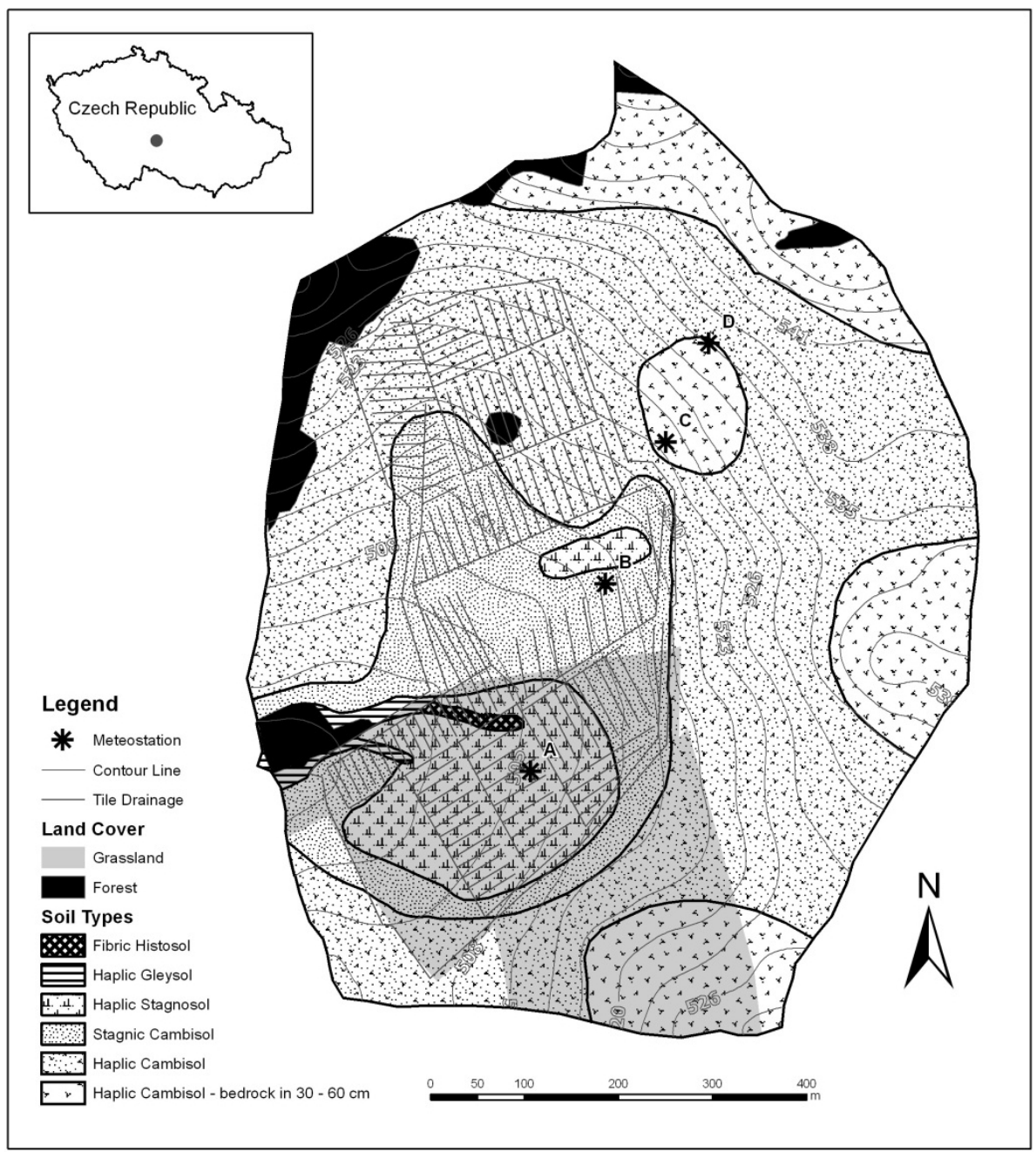

Figure 1. An overview map of the Dehtáre catchment and its soil types 
There is no permanent surface drainage channel within the catchment. The catchment hydrogeology is characterised by shallow aquifers (with groundwater table in the discharge zone lying at $0.2-1.5 \mathrm{~m}$ ), occurring in Quaternary deposits, in the weathered zone of the bedrock and in its fissures and faults. The bedrock is a partially migmatized paragneiss. Quaternary deposits are slope sands and bottom loams, reaching a thickness of 1-2 $\mathrm{m}$. The bottom loams usually act as aquitards and have their own phreatic groundwater table, partially recharged from the atmosphere, so that the water from below mixes in them with the water from above. The dominant soil types according to [22] (see Fig. 1) are Haplic Cambisols (CMha) in the recharge and transient zones. These soils are light, shallow and stony (the thickness of the soil profile being only $30 \mathrm{~cm}$ in some parts) sandy loams and loamy sands (according to the USDA soil texture triangle, see [23]). Haplic Stagnosols (STha), Haplic Gleysols, Fibric Histosols and Stagnic Cambisols (CMst) are typical for the discharge and the discharge/ transient zones. Medium-deep sandy loams dominate in the lower parts of the slopes, while deep loams are most typical for the catchment bottom. However, the spatial variability of grain size distribution in the soils of the catchment bottom makes surveying difficult. This variability is due to natural erosion and accumulation processes as well as due to artificial mixing which occurred during the tile drainage installation. The clay $(<0.002 \mathrm{~mm})$ content in the topsoil and subsoil varies from 10 to $13 \%$ and from 9 to $13 \%$, respectively, near the water divide, and from 12 to $15 \%$ and from 13 to $25 \%$, respectively, at the catchment bottom. A layer of clay loam was identified by geophysical survey [24,25] at the catchment bottom at the depth 30 to $200 \mathrm{~cm}$, in some places cropping up to the soil surface.

The tile drainage (still fully functioning) was laid in 1977 in the western, lower part of the catchment. The average slope of the drained land is about $5 \%$. The spacing of lateral drains is either 13 or $20 \mathrm{~m}$. The depth of the laterals is about $1.0 \mathrm{~m}$, while the depth of the mains is about $1.1 \mathrm{~m}$. Circumferential intercepting tile drains, provided with gravel filters, are placed at depths 1.1 to $1.8 \mathrm{~m}$. The tile drainage system empties into a fire water reservoir. Seasonal ascending springs, either point springs or spring lines, emerged in middle parts of the catchment slopes before the tile drainage system installation, causing temporary waterlogging of the lands [26, 27]. Today, the soils in the tile-drained north-western part of the catchment (Fig. 1) can be classified as CMha. Before the tile drainage installation they mainly belonged to the STha type.

Four weather stations (A, B, C, D - Fig. 1 and Table 1) were placed in the experimental catchment to record conditions on sites with different soil types and textures and in different relief zones. The stations A and B were located in the discharge and the discharge/transient zones, respectively (Table 1 ) on texturally heavier STha and CMst soils, where the terrain slope was $2-4^{\circ}$. The station B was placed in concentrated flow paths. The stations C and D were situated in the transient and the transient/recharge zones, respectively, on the CMha soil and the terrain slope $5-7^{\circ}$. Permeable loamy-sand soils under stations $C$ and D and between them are shallow; weathered bedrock can be found at $15-40 \mathrm{~cm}$ below the surface. Meteorological data of the station $\mathrm{C}$, based on prevailing wind direction, was markedly influenced by mentioned drying shallow bedrock and deeper, but tile drained CMha (Fig. 1). In addition to 
drying shallow bedrock the station $\mathrm{D}$ data was also significantly affected by deeper wetter soil without a drainage system.

\begin{tabular}{|c|c|c|c|c|c|c|c|c|c|c|c|c|}
\hline \multirow[t]{2}{*}{$\begin{array}{l}\text { Weather } \\
\text { station }\end{array}$} & \multirow[t]{2}{*}{ Terrain zone* } & \multirow[t]{2}{*}{$\begin{array}{l}\text { Altitude } \\
\text { (m) }\end{array}$} & \multirow[t]{2}{*}{ Soil type* } & \multirow[t]{2}{*}{$\begin{array}{c}\text { Textural class } \\
\text { Topsoil/ } \\
\text { subsoil* }\end{array}$} & \multicolumn{2}{|c|}{$\begin{array}{c}\text { Average clay } \\
\text { content* < } \\
\left.0.002 \mathrm{~mm}^{*} \%\right)\end{array}$} & \multicolumn{2}{|c|}{$\begin{array}{l}\text { Average sand } \\
\text { content* }^{*} \\
0.05-2.0 \mathrm{~mm} \\
(\%)\end{array}$} & \multirow{2}{*}{$\begin{array}{c}\text { Maximum } \\
\text { capillary } \\
\text { water } \\
\text { capacity** } \\
\text { (\% vol) at } \\
20-30 \mathrm{~cm}\end{array}$} & \multirow[t]{2}{*}{$\begin{array}{l}\text { Land } \\
\text { use }^{*}\end{array}$} & \multirow{2}{*}{$\begin{array}{c}\text { Tile- } \\
\text { drained } \\
\text { area* } \\
(\%)\end{array}$} & \multirow{2}{*}{ Slope $\left({ }^{\circ}\right)^{*}$} \\
\hline & & & & & topsoil & subsoil & topsoil & subsoil & & & & \\
\hline A & $\begin{array}{l}\text { Discharge } \\
\text { zone }\end{array}$ & 506 & $\begin{array}{c}\text { Haplic } \\
\text { Stagnosol } \\
\text { (STha) }\end{array}$ & $\begin{array}{l}\text { Silt loam or loam } \\
\text { or sandy loam } \\
\text { / Sandy loam or } \\
\text { loam or clay } \\
\text { loam }\end{array}$ & 12.3 & 16.1 & 48.3 & 48.4 & $\begin{array}{c}40.8 \\
\text { (topsoil) }\end{array}$ & grassland & 100 & $2-3$ \\
\hline B & $\begin{array}{l}\text { Discharge/ } \\
\text { transient } \\
\text { zone } \\
\text { (in } \\
\text { concentrated } \\
\text { flow paths) }\end{array}$ & 513 & $\begin{array}{c}\text { Stagnic } \\
\text { Cambisol } \\
\text { (CMst), } \\
\text { Haplic } \\
\text { Stagnosol } \\
\text { (STha) }\end{array}$ & $\begin{array}{l}\text { Loam } \\
\text { / Sandy loam or } \\
\text { loam (STha) }\end{array}$ & $\begin{array}{c}12.3 \\
\text { (CMSt) } \\
16.5 \\
\text { (STha) }\end{array}$ & $\begin{array}{c}10.6 \\
\text { (CMSt) } \\
14.9 \\
\text { (STha) }\end{array}$ & $\begin{array}{c}48.5 \\
\text { (CMSt) } \\
44.4 \\
\text { (STha) }\end{array}$ & $\begin{array}{c}62.2 \\
\text { (CMSt) } \\
53.5 \\
\text { (STha) }\end{array}$ & $\begin{array}{c}39.8 \\
\text { (subsoil) }\end{array}$ & $\begin{array}{l}\text { arable } \\
\text { land }\end{array}$ & 69 & $3-4$ \\
\hline C & $\begin{array}{c}\text { Transient } \\
\text { zone }\end{array}$ & 523 & $\begin{array}{l}\text { Haplic } \\
\text { Cambisol } \\
\text { (CMha) }\end{array}$ & $\begin{array}{l}\text { Sandy loam or } \\
\text { loamy sand } \\
\text { /Sandy loam or } \\
\text { loamy sand }\end{array}$ & 11.0 & 11.7 & 66.9 & 62.2 & $\begin{array}{c}30.4 \\
\text { (subsoil) }\end{array}$ & $\begin{array}{l}\text { arable } \\
\text { land }\end{array}$ & 29 & $5-6$ \\
\hline D & $\begin{array}{l}\text { Transient/ } \\
\text { recharge zone }\end{array}$ & 534 & $\begin{array}{l}\text { Haplic } \\
\text { Cambisol } \\
\text { (CMha) }\end{array}$ & $\begin{array}{l}\text { Sandy loam or } \\
\text { loamy sand } \\
\text { /Sandy loam or } \\
\text { loamy sand }\end{array}$ & 12.6 & 10.7 & 62.5 & 66.2 & $\begin{array}{c}30.3 \\
\text { (subsoil) }\end{array}$ & $\begin{array}{l}\text { arable } \\
\text { land }\end{array}$ & 0 & $6-7$ \\
\hline within a 1 & $0 \mathrm{~m}$ radius circle & round & $\mathrm{h}$ weather & & & & & & & & & \\
\hline
\end{tabular}

Table 1. Location, soils, land use, tile-drainage and terrain conditions around the weather stations $A$ to $D$ in the Dehtáře catchment

Each station was equipped with an ETa-measuring system, which comprised a datalogger (MiniCube VV/VX, EMS Brno, CZ), two air temperature and two air relative humidity sensors (EMS 33, EMS Brno, CZ), selected pairwise to have similar characteristics and placed at 0.51.5 and 2.0-2.4 $\mathrm{m}$ above the ground, depending on the crop growth stage, a net radiometer (Schenk 8110, Philipp Schenk, AT, thermal principle, stability 3\% per year), soil temperature sensors (PT 100/8, EMS Brno) at 0.1 and $0.2 \mathrm{~m}$ and a soil heat flux meter (HFP01, Hukseflux, $\mathrm{NL}$ ). The stations $\mathrm{B}, \mathrm{C}$ and $\mathrm{D}$ were operating during the growing season. The station $\mathrm{A}$, operating year round, was in addition equipped with a pyranometer for measuring global radiation (EMS 11, EMS Brno, CZ, silicone diode sensor, calibration error under daylight condition max. $7 \%$ ) and a wind sensors measuring wind speed and direction (Met One 034B, Met One, Oregon, U.S.A., $0.28 \mathrm{~m} \mathrm{~s}^{-1}$ starting threshold) placed at $2 \mathrm{~m}$ height. All stations recorded their data at one-minute intervals, while the dataloggers saved only 10 min averages.

The station A was surrounded by permanent grassland cut three times a year (end of May, second half of July and second half of October). Winter wheat was cultivated in the vicinity of 
the stations B, C and D in 2004 (sown 20 Sept. 2003, harvested 25 July 2004), winter rape was there in 2006 (sown 22 Aug. 2005, harvested 1 Aug. 2006) and spring barley in 2009 (sown 8 March, harvested 7 Aug. 2009); the latter was a cover crop for red clover.

\section{Determination of actual evapotranspiration rate}

ETa was determined from the latent heat flux (LE) in the simplified energy balance equation [28]:

$$
R n=G+L E+H\left(\mathrm{~W} \mathrm{~m}^{-2}\right)
$$

where Rn (net radiation) and G (soil heat flux) could be directly measured with a sufficient accuracy and $\mathrm{H}$ (turbulent sensible-heat flux) was calculated from the Bowen ratio $(\beta)$. The turbulent diffusion theory admits that, under some assumptions, the Bowen ratio can be calculated from the vertical air temperature and vapour pressure gradients. The basic assumptions are the equality of transport coefficients for vertical turbulent transport of heat and water vapour under conditions the neutral atmosphere stratification and a flat homogenous extensive plant cover over a certain distance upwind of the point of observation (fetch), ensuring that the gradient measurements can be made within the equilibrium sublayer, where the fluxes are assumed to be independent of height [29-32]. The thickness of the equilibrium sublayer for an aerodynamically smooth-to-rough transition is assumed to be $10 \%$ of the internal boundary layer thickness $\delta$. The latter can be calculated using the Munro \& Oke (1975) equation (cited in [29]):

$$
\delta=x^{0.8} \cdot z_{0}^{0.2}(\mathrm{~m})
$$

where $\mathrm{x}$ is the fetch and $\mathrm{z}_{0}$ is the momentum roughness length of the crop surface (it can be taken as $13 \%$ of the crop height).

The adequate fetch length for the internal boundary layer to be of sufficient thickness (2.0 to $2.5 \mathrm{~m}$ above the ground, depending on the crop height) can be then estimated as:

$$
x=\left(\delta / z_{0}^{0.2}\right)^{1.25}(\mathrm{~m})
$$

The Bowen ratio $\beta$ is defined as:

$$
\beta=\frac{H}{L E}
$$


After substitution from the equations of vertical turbulent heat and mass transport $[28,33]$ and after introduction of the psychrometric constant $\gamma\left(\mathrm{kPa}^{\circ} \mathrm{C}^{-1}\right)$ is obtained:

$$
\beta=\gamma \frac{\left(T_{2}-T_{1}\right)}{(e 2-e 1)}
$$

where $\left(\mathrm{T}_{2}-\mathrm{T}_{1}\right) /\left(\mathrm{e}_{2}-\mathrm{e}_{1}\right)$ is the ratio of the air temperature $\left({ }^{\circ} \mathrm{C}\right)$ and vapour pressure $(\mathrm{kPa})$ vertical gradients above the plant canopy.

ETa can be calculated by combining equations (1) and (4):

$$
E T a=\frac{R n-G}{L(1+\beta)} \cdot 3600\left(\mathrm{~mm} \mathrm{~h}^{-1}\right)
$$

where $\mathrm{L}$ is the latent heat of vaporization $\left(\mathrm{J} \mathrm{kg}^{-1}\right)$ and $1 \mathrm{~mm}$ of water is taken as $1 \mathrm{~kg} \mathrm{~m}^{-2}$.

Conditions needed to fulfil theoretical requirements for using this method usually cannot be achieved in the early morning, evening and night periods and sometimes even on cloudy or rainy days or on days with significant advection. Therefore, the cases when $|R n-G| \leq 10 \mathrm{~W}$ $\mathrm{m}^{-2}$ or $\beta<-0.1$ or $\beta>4$ or $\mathrm{LE}=0$ or when simultaneously $\mathrm{LE}<0$ and $\mathrm{H}>0$ were excluded from further processing. In this way, it was ensured that the situations when the gradients of air temperature and vapour pressure had opposite or uncertain signs (due to insufficient resolution limits of the sensors or due to advection) or when the stratification was strongly instable (far from neutral) [34, 35] were not taken into account. Table 2 shows Bowen ratio data excluded, which comprises $\beta<-0.1$ or $\beta>4$; Table 3 rejects ETa values with this "unfavourable" Bowen ratios in conjuction with all other cases mentioned above. During the periods of vapour condensation at the surface under conditions of nocturnal inversion and outgoing available energy $(\mathrm{LE}<0$ and $H<0)$, the equilibrium evaporation $\Delta(\mathrm{Rn}-\mathrm{G}) /(\Delta+\gamma)$, which is negative under these conditions, was set as a lower limit of vapour condensation, i.e., the absolute value of the actual condensation could not be higher than the absolute value of this equilibrium evaporation [35]. The missing ETa values for the periods thus excluded were estimated based on linear regression between the valid ETa values and the equilibrium evaporation. Then the summation of the resulting uninterrupted series of 10-min ETa values gave the average daily ETa rates in $\mathrm{mm} \mathrm{h}^{-1}$ and these were subsequently converted to daily totals of ETa in $\mathrm{mm} \mathrm{d}^{-1}$.

\section{Measurement of precipitation and maximum capillary water capacity and the soil textural class estimation}

A tipping-bucket rain gauge $276 \mathrm{~mm}$ in diameter (with the interception surface $0.06 \mathrm{~m}^{2}$ ) was located near the centre of the catchment. Each tip corresponded to $0.1 \mathrm{~mm}$ increment of precipitation. The precipitation totals were recorded at 10-min intervals. 
Both disturbed and undisturbed soil samples were taken at about $100 \mathrm{~m}$ distance from each weather station from both topsoil and subsoil. To assess the moisture-holding capacity of the soil, an empirical characteristic of the soil water retention capacity was determined in the laboratory according to Novák's procedure [36]. It is referred to as the maximum capillary water capacity (MCWC). The procedure consists of allowing an undisturbed soil sample (100 $\left.\mathrm{cm}^{3}\right)$, previously fully soaked with water by capillarity from below, to drain by suction on a layer of filter paper over $2 \mathrm{~h}$. Its moisture content at the end of the period is MCWC. [37] declares that MCWC corresponds approximately to the field capacity of the soil. The grain size distribution of the soil was determined according to [38]. It was expressed in percent by mass of individual particle size fractions (clay: $<0.002 \mathrm{~mm}$, silt: $0.002-0.05 \mathrm{~mm}$, sand: $0.05-2.00 \mathrm{~mm}$ ). The soil texture was classified according to the USDA [23] soil texture triangle.

\section{Statistical analysis}

To assess the systematic effect of the categorical independent variable "weather station" (including soil type, crop, tile drainage and terrain position) upon the dependent quantitative variable (daily ETa) a paired t-test was used, in order to indicate whether or not the expected difference between two matching observations is zero (the null hypothesis), taking the probability of unwarranted rejection of the null hypothesis $\mathrm{p}=0.05$. The period of spring and early summer was separately tested, i.e., from May to mid-July (period 1, up to crop maturity), and the following period of summer from mid-July to mid-August (period 2, after crop maturity). The latter period ended shortly after the crop harvest (in the case of field crops) or in the middle of the interval between the second and the third grass cutting.

\section{Bowen ratio and actual evapotranspiration values exlusion, FETCH determination}

Table 2 shows the number of all Bowen ratio $(\beta)$ values obtained in individual periods and years and the percentage of values excluded. Of all 10-min $\beta$ values measured at individual weather stations, $19-27 \%$ were rejected (these and the following values being taken over the entire period of observation). Seventy-four to $84 \%$ of the rejected values were night measurements (between 19:10 and 05:50). Of the night-time $\beta$ values, 36-43\% were rejected, compared with $8-13 \%$ rejection rate of daytime $\beta$ values (not shown in Table 2). These results agree with those by [32] who reported $29 \%$ and $9 \%$ of $\beta$ values rejected at night and in daytime, respectively.

Altogether, 32-40\% of 10-min ETa measurements were invalid (Table 3), according to the criteria set forth in the part 4 . Seventy-one to $84 \%$ of the invalid data points occurred at night, when ETa values tended toward zero (being either very small positive or very small negative). Of the night-time ETa measurements, $62-70 \%$ were invalid, as opposed to the daytime ETa pattern, when $11.5-15 \%$ were invalid. 


\begin{tabular}{|c|c|c|c|c|c|c|c|c|c|c|c|c|}
\hline \multirow[b]{2}{*}{ Period } & \multicolumn{3}{|c|}{ Weather station A } & \multicolumn{3}{|c|}{ Weather station B } & \multicolumn{3}{|c|}{ Weather station C } & \multicolumn{3}{|c|}{ Weather station D } \\
\hline & $\begin{array}{l}\text { All } \beta \\
\text { data }\end{array}$ & $\begin{array}{c}\text { All } \beta \\
\text { data } \\
\text { excluded } \\
(\%)\end{array}$ & $\begin{array}{l}\text { Night- } \\
\text { time } \beta \\
\text { data } \\
\text { excluded } \\
(\%)\end{array}$ & $\begin{array}{l}\text { All } \beta \\
\text { data }\end{array}$ & $\begin{array}{c}\text { All } \beta \\
\text { data } \\
\text { excluded } \\
(\%)\end{array}$ & $\begin{array}{l}\text { Night- } \\
\text { time } \beta \\
\text { data } \\
\text { excluded } \\
(\%)\end{array}$ & $\begin{array}{l}\text { All } \beta \\
\text { data }\end{array}$ & $\begin{array}{c}\text { All } \beta \\
\text { data } \\
\text { excluded } \\
(\%)\end{array}$ & $\begin{array}{l}\text { Night- } \\
\text { time } \beta \\
\text { data } \\
\text { excluded } \\
(\%)\end{array}$ & $\begin{array}{l}\text { All } \beta \\
\text { data }\end{array}$ & $\begin{array}{c}\beta \text { data } \\
\text { excluded } \\
(\%)\end{array}$ & $\begin{array}{c}\text { Night- } \\
\text { time } \beta \\
\text { data } \\
\text { excluded } \\
(\%)\end{array}$ \\
\hline $\begin{array}{c}2004 \\
29 \\
\text { May-12 } \\
\text { Aug }\end{array}$ & $\begin{array}{c}1065 \\
6\end{array}$ & 18.5 & $\begin{array}{l}16.1^{\star} \\
(87)^{\star \star}\end{array}$ & $\begin{array}{c}1094 \\
4\end{array}$ & 27.8 & $\begin{array}{c}17.4^{\star} \\
(62.8)^{\star \star}\end{array}$ & $\begin{array}{c}1094 \\
4\end{array}$ & 33.5 & $\begin{array}{c}24.5^{\star} \\
(73.1)^{\star \star}\end{array}$ & $\begin{array}{c}1094 \\
3\end{array}$ & 26.6 & $\begin{array}{c}20.1^{\star} \\
(75.6)^{\star \star}\end{array}$ \\
\hline $\begin{array}{c}2006 \\
6 \\
\text { May-19 } \\
\text { Aug }\end{array}$ & $\begin{array}{c}1526 \\
4\end{array}$ & 16.7 & $\begin{array}{c}13.6^{*} \\
(81.5)^{\star *}\end{array}$ & $\begin{array}{c}1526 \\
4\end{array}$ & 24.2 & $\begin{array}{c}17.0^{\star} \\
(70.4)^{\star *}\end{array}$ & $\begin{array}{c}1526 \\
4\end{array}$ & 25.0 & $\begin{array}{c}19.1^{\star} \\
(76.5)^{\star \star}\end{array}$ & $\begin{array}{c}1518 \\
7\end{array}$ & 25.4 & $\begin{array}{c}22.7^{*} \\
(89.5)^{\star *}\end{array}$ \\
\hline $\begin{array}{c}2009 \\
1 \\
\text { May-23 } \\
\text { Aug }\end{array}$ & $\begin{array}{c}1656 \\
0\end{array}$ & 22.5 & $\begin{array}{c}13.8^{*} \\
(61.5)^{\star \star}\end{array}$ & $\begin{array}{c}1656 \\
0\end{array}$ & 13.6 & $\begin{array}{c}11.9^{\star} \\
(87.5)^{\star \star}\end{array}$ & $\begin{array}{c}1656 \\
0\end{array}$ & 19.6 & $\begin{array}{c}15.9^{*} \\
(81.0)^{\star \star}\end{array}$ & $\begin{array}{c}1655 \\
6\end{array}$ & 28.1 & $\begin{array}{c}24.3^{*} \\
(86.5)^{\star *}\end{array}$ \\
\hline Average & & 19.2 & $\begin{array}{c}14.5^{\star} \\
(76.7)^{\star \star}\end{array}$ & & 21.9 & $\begin{array}{c}15.4^{*} \\
(73.6)^{\star *}\end{array}$ & & 26.0 & $\begin{array}{c}19.8^{\star} \\
(76.9)^{\star \star}\end{array}$ & & 26.7 & $\begin{array}{c}22.4^{\star} \\
(83.9)^{\star \star}\end{array}$ \\
\hline related & 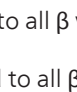 & values & ccluded & & & & & & & & & \\
\hline
\end{tabular}

Table 2. Total number of 10-min Bowen ratio $(\beta)$ values and the percentage of values excluded in individual periods

\begin{tabular}{|c|c|c|c|c|c|c|c|c|c|c|c|c|}
\hline \multirow[b]{2}{*}{ Period } & \multicolumn{3}{|c|}{ Weather station A } & \multicolumn{3}{|c|}{ Weather station B } & \multicolumn{3}{|c|}{ Weather station C } & \multicolumn{3}{|c|}{ Weather station D } \\
\hline & $\begin{array}{l}\text { All } \\
\text { ETa } \\
\text { data }\end{array}$ & $\begin{array}{c}\text { All ETa } \\
\text { data } \\
\text { excluded } \\
(\%)\end{array}$ & $\begin{array}{l}\text { Night- } \\
\text { time ETa } \\
\text { data } \\
\text { excluded } \\
(\%)\end{array}$ & $\begin{array}{c}\text { All } \\
\text { ETa } \\
\text { data }\end{array}$ & $\begin{array}{c}\text { All ETa } \\
\text { data } \\
\text { excluded } \\
(\%)\end{array}$ & $\begin{array}{l}\text { Night- } \\
\text { time ETa } \\
\text { data } \\
\text { excluded } \\
(\%)\end{array}$ & $\begin{array}{c}\text { All } \\
\text { ETa } \\
\text { data }\end{array}$ & $\begin{array}{c}\text { All ETa } \\
\text { data } \\
\text { excluded } \\
(\%)\end{array}$ & $\begin{array}{c}\text { Night- } \\
\text { time ETa } \\
\text { data } \\
\text { excluded } \\
(\%)\end{array}$ & $\begin{array}{c}\text { All } \\
\text { ETa } \\
\text { data }\end{array}$ & $\begin{array}{c}\text { ETa data } \\
\text { excluded } \\
(\%)\end{array}$ & $\begin{array}{l}\text { Night- } \\
\text { time ETa } \\
\text { data } \\
\text { excluded } \\
(\%)\end{array}$ \\
\hline $\begin{array}{c}2004 \\
29 \\
\text { May-12 } \\
\text { Aug }\end{array}$ & $\begin{array}{c}1065 \\
6\end{array}$ & 27.6 & $\begin{array}{c}14.6^{\star} \\
(53)^{\star *}\end{array}$ & $\begin{array}{c}1094 \\
4\end{array}$ & 36.5 & $\begin{array}{c}25.4^{\star} \\
(69.6)^{\star *}\end{array}$ & $\begin{array}{c}1094 \\
4\end{array}$ & 41.7 & $\begin{array}{c}31.4^{\star} \\
(75.4)^{\star *}\end{array}$ & $\begin{array}{c}1094 \\
3\end{array}$ & 38.9 & $\begin{array}{c}30.9^{*} \\
(79.5)^{\star *}\end{array}$ \\
\hline $\begin{array}{c}2006 \\
6 \\
\text { May-19 } \\
\text { Aug }\end{array}$ & $\begin{array}{c}1526 \\
4\end{array}$ & 28.1 & $\begin{array}{c}23.1^{\star} \\
(82.3)^{\star *}\end{array}$ & $\begin{array}{c}1526 \\
4\end{array}$ & 41.5 & $\begin{array}{c}33.1^{\star} \\
(79.8)^{\star \star}\end{array}$ & $\begin{array}{c}1526 \\
4\end{array}$ & 32.5 & $\begin{array}{c}25.2^{\star} \\
(77.4)^{\star *}\end{array}$ & $\begin{array}{c}1518 \\
7\end{array}$ & 36.8 & $\begin{array}{c}32.3^{*} \\
(87.8)^{\star *}\end{array}$ \\
\hline $\begin{array}{c}2009 \\
1 \\
\text { May-23 } \\
\text { Aug }\end{array}$ & $\begin{array}{c}1656 \\
0\end{array}$ & 41.5 & $\begin{array}{c}31.8^{\star} \\
(76.7)^{\star \star}\end{array}$ & $\begin{array}{c}1656 \\
0\end{array}$ & 40.6 & $\begin{array}{c}35.5^{\star} \\
(87.5)^{\star \star}\end{array}$ & $\begin{array}{c}1656 \\
0\end{array}$ & 31.7 & $\begin{array}{c}25.7^{\star} \\
(80.9)^{\star \star}\end{array}$ & $\begin{array}{c}1655 \\
6\end{array}$ & 38.8 & $\begin{array}{c}32.7^{\star} \\
(84.1)^{\star *}\end{array}$ \\
\hline Average & & 32.4 & $\begin{array}{c}23.2^{\star} \\
(70.7)^{\star \star}\end{array}$ & & 39.5 & $\begin{array}{c}31,3^{*} \\
(79.0)^{\star *}\end{array}$ & & 35.3 & $\begin{array}{c}27.4^{\star} \\
(77.9)^{\star \star}\end{array}$ & & 38.2 & $\begin{array}{c}32.0^{*} \\
(83.8)^{\star *}\end{array}$ \\
\hline${ }^{\star}$ related & all E & Ta values & excluded & & & & & & & & & \\
\hline
\end{tabular}

Table 3. Total number of 10-min ETa values and the percentage of values excluded in individual periods 
The accuracy of the BREB method of ETa determination, provided that its theoretical assumptions are met, is approximately $10 \%[31,35]$. The thickness of the equilibrium sublayer is related to the fetch. It is recommended that the minimum fetch to upper measurement height ratio is at least 10:1 to 200:1, with 100:1 being considered adequate for most measurements. The BREB method is less sensitive to imperfect fetch conditions than other techniques, if the Bowen ratio is small (c. 0.3-0.4, [39]). According to [29], a significant boundary-layer adjustment occurs within the first $15 \mathrm{~m}$ of the fetch and, hence, when the Bowen ratio is small, the method can be used successfully at fetch-to-height ratios as low as 20:1, despite the fact that the measurements are not made strictly within the equilibrium sublayer. [32] show fetches ranging from $90 \mathrm{~m}$ to $360 \mathrm{~m}$, [40] mention a sufficient fetch of 148-168 m.

In this case, considering the crop height of 0.4 to $1.5 \mathrm{~m}$ (cereals, rape) and an adequate equilibrium sublayer thickness of 2.0-2.5 m, a sufficient minimum fetch, according to Eq. 3, is $80-90 \mathrm{~m}$. The prevailing wind directions observed were $60-120^{\circ}$ and $210-300^{\circ}$. The actual wind direction remained within these two directions over $67.0 \%$ of the time in 2004 , over $59.3 \%$ of the time in 2006 and over $64.6 \%$ of the time in 2009 . The particular weather stations were far enough apart related to the minimum fetch, their mutual distances being $114 \mathrm{~m}$ (C-D), $175 \mathrm{~m}$ (B-C) and $204 \mathrm{~m}$ (A-B). The distances any of A, B, C and D from the upwind boundary of the crop stand were in most cases greater than $80-90 \mathrm{~m}$. The minimum and maximum fetches were 95-300 $\mathrm{m}$ and 180-510 $\mathrm{m}$, respectively, along the prevailing wind directions. Hence, no significant footprint overlapping of the weather stations occurred. The fetch of the station B from the permanent grassland boundary varied between $68 \mathrm{~m}$ and $90 \mathrm{~m}$, if the wind direction varied between $125^{\circ}$ and $215^{\circ}$. However, only $20-27 \%$ of wind directions measured lay within this interval. With the wind direction within this interval and considering only the Bowen ratios $\beta>0.4$ (for which greater sensitivity to the perfectness of the fetch was expected), only another $10-14 \%$ of $\beta$ values and $8-9 \%$ of ETa values would have been rejected. Based on this analysis, the fetches of all weather stations were considered sufficient and no data were rejected because of "wrong" wind directions. Of all ETa data considered valid and measured by the stations B and C, 70\% and 57\%, respectively, were influenced by the nearby tile-drained area. This happened when the wind direction was $25^{\circ}-250^{\circ}$ at station $B$ and $160^{\circ}-295^{\circ}$ at station $C$.

\section{Between-stations ETa and Bowen comparison}

The soils around the stations A to D are characterized by markedly differing grain size distribution, which influenced their water retention capacity (Table 1). The Haplic Stagnosols and Stagnic Cambisols on which weather stations A and B were located display lower sand content in the topsoil as compared to the Haplic Cambisols around the stations C and D. However, all varieties of Cambisols (around the stations B, C and D) contain more sand in the subsoil than the Stagnosols. The actual soil water retention capacity was influenced not only by the sand and clay content but also by the presence of tile-drainage systems around the stations A, B, C and terrain relief (see Fig. 1 and Table 1).

The soils surrounding the station $C$, with the highest content of sand and partially influenced by the adjacent drainage system, manifested themselves in the lowest ETa values and the 
highest $\beta$ over all three years (Table 4, Figs. 2-7). In contrast, the fine-textured soils with greater MCWC and affected more by the shallow groundwater table and the shallow lateral flow (STha, CMst, stations A and B), showed in most cases the highest ETa values. The findings by $[2,41-42]$ in this respect are similar.

\begin{tabular}{|c|c|c|c|c|c|c|c|c|c|}
\hline \multirow{2}{*}{$\begin{array}{l}\text { Year and } \\
\text { the crop } \\
\text { around } \\
\text { stations B } \\
\text { to D }\end{array}$} & \multirow[b]{2}{*}{ Station } & \multicolumn{3}{|c|}{ Average daily ETa (mm) } & \multicolumn{3}{|c|}{ Average daily Bowen ratio $\beta(-)$} & \multicolumn{2}{|c|}{$\begin{array}{l}\text { Precipitation }(\mathrm{mm}) \text { : } \\
\text { Total over period/ } \\
\text { Daily average }\end{array}$} \\
\hline & & $\begin{array}{l}\text { May to } \\
\text { mid-July } \\
\text { (up to } \\
\text { crop } \\
\text { maturity) }\end{array}$ & $\begin{array}{l}\text { Mid-July } \\
\text { to mid- } \\
\text { August } \\
\text { (after crop } \\
\text { maturity) }\end{array}$ & $\begin{array}{l}\text { Entire } \\
\text { growing } \\
\text { season }\end{array}$ & $\begin{array}{l}\text { May to } \\
\text { mid-July } \\
\text { (up to } \\
\text { crop } \\
\text { maturity) }\end{array}$ & $\begin{array}{l}\text { Mid-July } \\
\text { to mid- } \\
\text { August } \\
\text { (after crop } \\
\text { maturity) }\end{array}$ & $\begin{array}{l}\text { Entire } \\
\text { growing } \\
\text { season }\end{array}$ & $\begin{array}{l}\text { May to } \\
\text { mid-July } \\
\text { (up to crop } \\
\text { maturity) }\end{array}$ & $\begin{array}{c}\text { Mid-July to } \\
\text { mid-August } \\
\text { (after crop } \\
\text { maturity) }\end{array}$ \\
\hline \multirow{4}{*}{$\begin{array}{c}2004 \\
\text { Winter } \\
\text { wheat }\end{array}$} & $A^{*}$ & $2.97 \pm 1.18$ & $3.46 \pm 0.76$ & $3.15 \pm 1.06$ & $0.32 \pm 0.11$ & $0.40 \pm 0.15$ & $0.35 \pm 0.13$ & \multirow{4}{*}{$109.8 / 2.29$} & \multirow{4}{*}{$6.4 / 0.22$} \\
\hline & $\mathrm{B}$ & $3.52 \pm 1.34$ & $2.38 \pm 1.24$ & $3.10 \pm 1.41$ & $0.26 \pm 0.12$ & $1.53 \pm 1.02$ & $0.71 \pm 0.86$ & & \\
\hline & C & $2.68 \pm 1.04$ & $1.75 \pm 1.00$ & $2.34 \pm 1.11$ & $0.46 \pm 0.17$ & $1.66 \pm 1.09$ & $0.83 \pm 0.82$ & & \\
\hline & $\mathrm{D}$ & $3.15 \pm 1.15$ & $2.26 \pm 0.90$ & $2.83 \pm 1.15$ & $0.41 \pm 0.15$ & $1.98 \pm 1.15$ & $0.99 \pm 1.04$ & & \\
\hline \multirow{4}{*}{$\begin{array}{c}2006 \\
\text { Winter rape }\end{array}$} & $A^{*}$ & $3.43 \pm 1.39$ & $2.96 \pm 1.58$ & $3.27 \pm 1.47$ & $0.47 \pm 0.25$ & $0.47 \pm 0.27$ & $0.47 \pm 0.25$ & \multirow{4}{*}{$222.3 / 3.18$} & \multirow{4}{*}{$126.3 / 3.41$} \\
\hline & $\mathrm{B}$ & $3.37 \pm 1.39$ & $3.15 \pm 1.39$ & $3.29 \pm 1.38$ & $0.53 \pm 0.32$ & $0.40 \pm 0.21$ & $0.49 \pm 0.30$ & & \\
\hline & C & $3.20 \pm 1.37$ & $2.44 \pm 1.29$ & $2.94 \pm 1.39$ & $0.61 \pm 0.29$ & $0.93 \pm 0.51$ & $0.72 \pm 0.41$ & & \\
\hline & $\mathrm{D}$ & $3.28 \pm 1.24$ & $2.66 \pm 1.27$ & $3.07 \pm 1.28$ & $0.66 \pm 0.27$ & $0.85 \pm 0.31$ & $0.73 \pm 0.30$ & & \\
\hline \multirow{4}{*}{$\begin{array}{c}2009 \\
\text { Spring } \\
\text { barley as a } \\
\text { cover crop } \\
\text { for red } \\
\text { clover }\end{array}$} & $A^{*}$ & $3.06 \pm 1.31$ & $3.65 \pm 1.33$ & $3.26 \pm 1.34$ & $0.35 \pm 0.27$ & $0.27 \pm 0.30$ & $0.32 \pm 0.28$ & \multirow{4}{*}{$207.2 / 2.73$} & \multirow{4}{*}{$109.1 / 2.73$} \\
\hline & $B$ & $3.09 \pm 1.44$ & $3.19 \pm 1.06$ & $3.13 \pm 1.32$ & $0.40 \pm 0.16$ & $0.50 \pm 0.17$ & $0.43 \pm 0.17$ & & \\
\hline & C & $2.67 \pm 1.12$ & $2.60 \pm 0.74$ & $2.65 \pm 1.00$ & $0.59 \pm 0.23$ & $0.81 \pm 0.38$ & $0.67 \pm 0.31$ & & \\
\hline & D & $3.05 \pm 1.29$ & $3.47 \pm 1.12$ & $3.20 \pm 1.25$ & $0.36 \pm 0.16$ & $0.30 \pm 0.14$ & $0.34 \pm 0.15$ & & \\
\hline
\end{tabular}

*Station A is surrounded by grassland

Table 4. Average actual evapotranspiration (ETa) and Bowen ratio $(\beta)$ values \pm their standard deviations, precipitation totals and daily averages for the weather stations $A$ to $D$ in individual years and periods

\subsection{Dry weather conditions}

The reported differences in daily ETa were related to the periods of limited transpiration either due to the onset of crop maturity (when the plant water consumption was already low and the excessive precipitation was absorbed by the soil) and/or due to drought (when the soil water supply to plants was limited). Hence, in some cases (in period 2 but, in 2004, also in the second half of period 1 - from late June to mid-July), the statistical tests signalled systematic ETa differences between different soil types under different land use (mostly A vs. C) and even between different soil types under the same land use (always B vs. C, mostly D vs. C, Table 5). It means that the fine-textured soils in the discharge and discharge/transient zones, having higher MCWC and affected more by shallow groundwater table or/and shallow subsurface flow due to concentrated flow paths (STha, CMst, stations A and B) were marked in most cases 


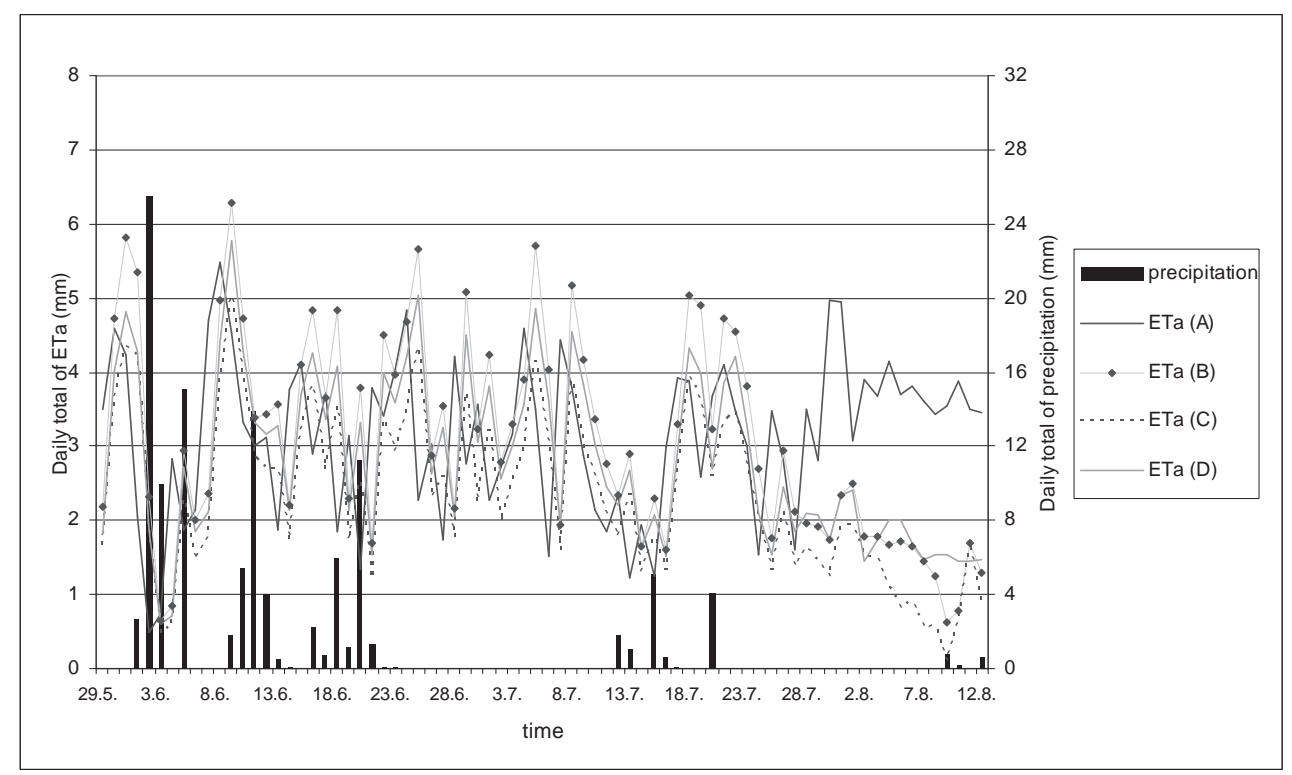

Figure 2. Average daily values of actual evapotranspiration for the Dehtáre catchment, 2004

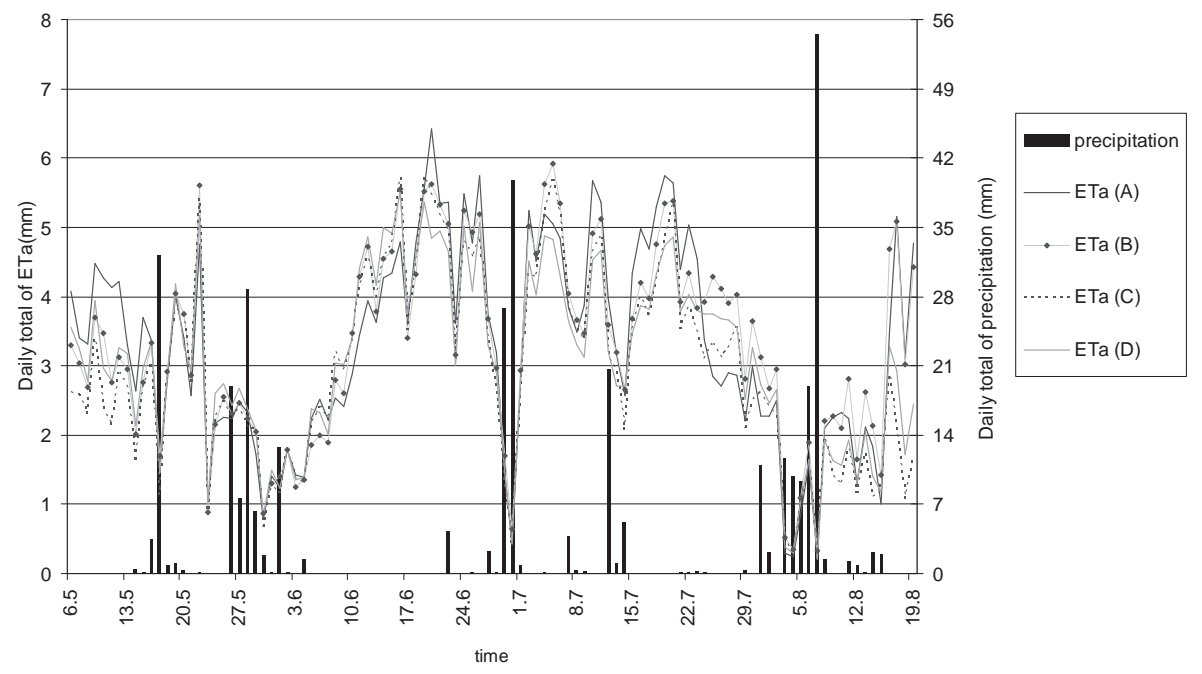

Figure 3. Average daily values of actual evapotranspiration for the Dehtáre catchment, 2006 


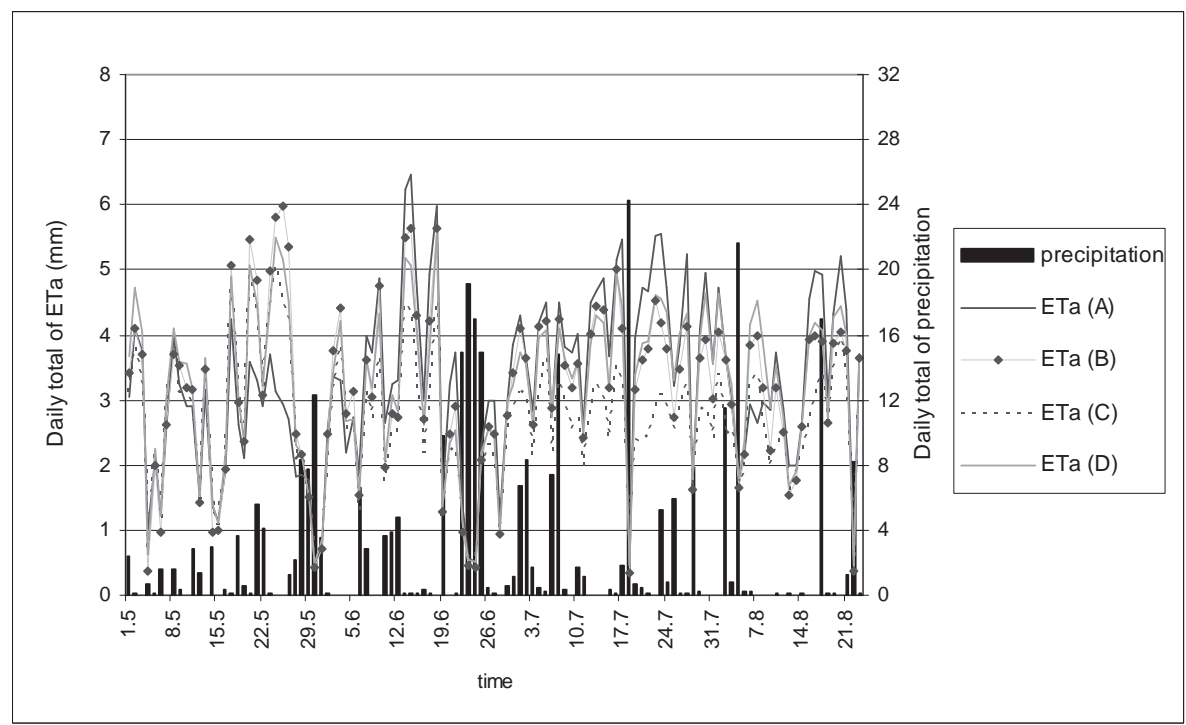

Figure 4. Average daily values of actual evapotranspiration for the Dehtáre catchment, 2009

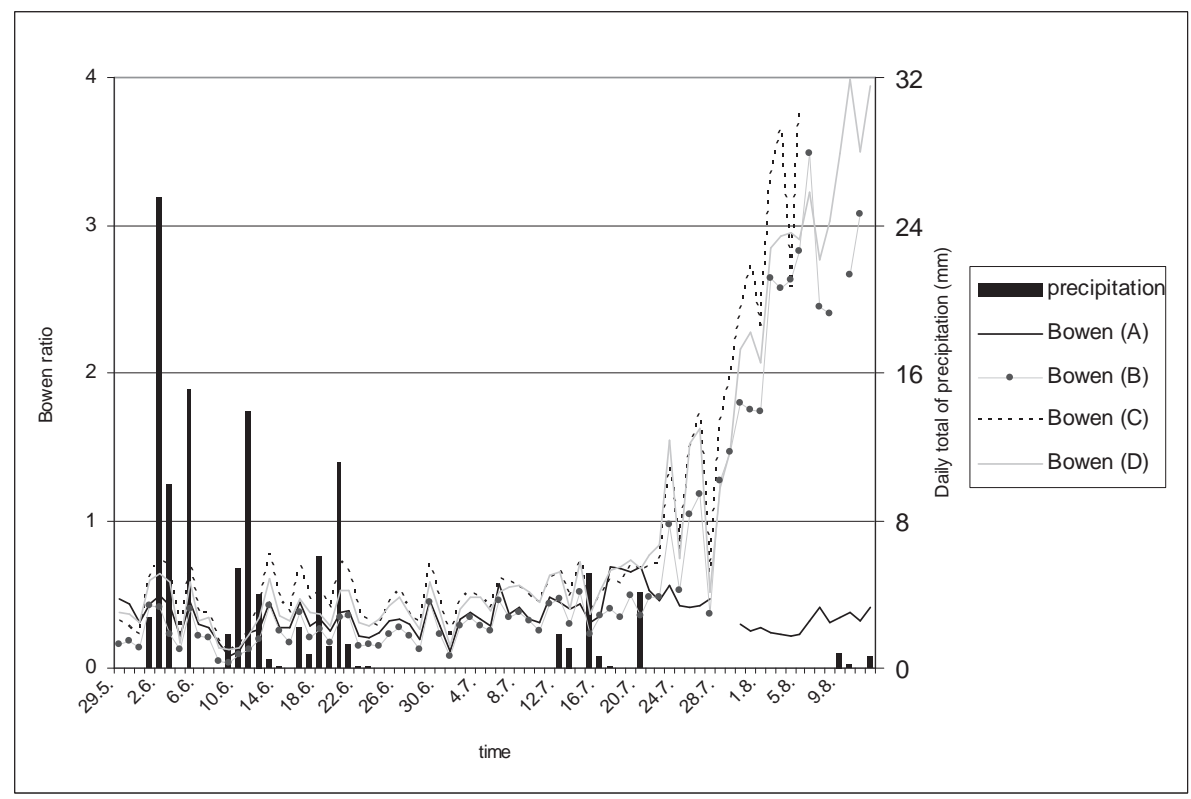

Figure 5. Average daily values of the Bowen ratio for the Dehtáre catchment, 2004 


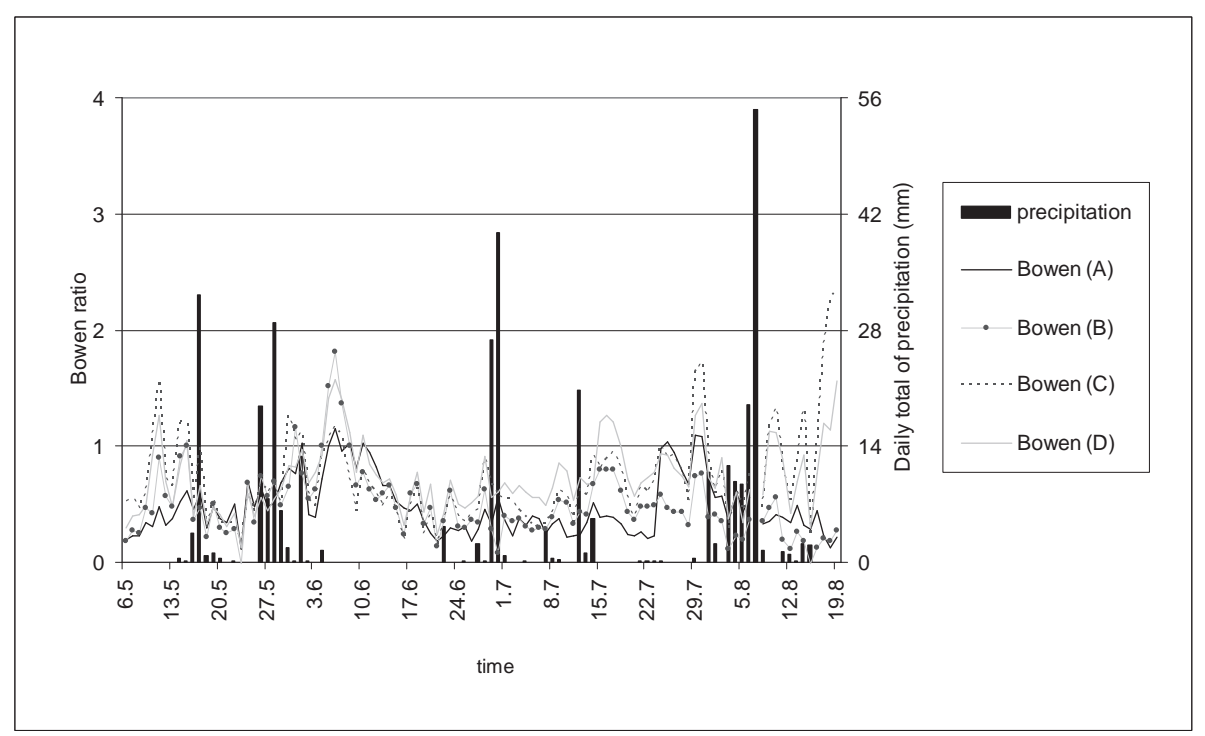

Figure 6. Average daily values of the Bowen ratio for the Dehtáře catchment, 2006

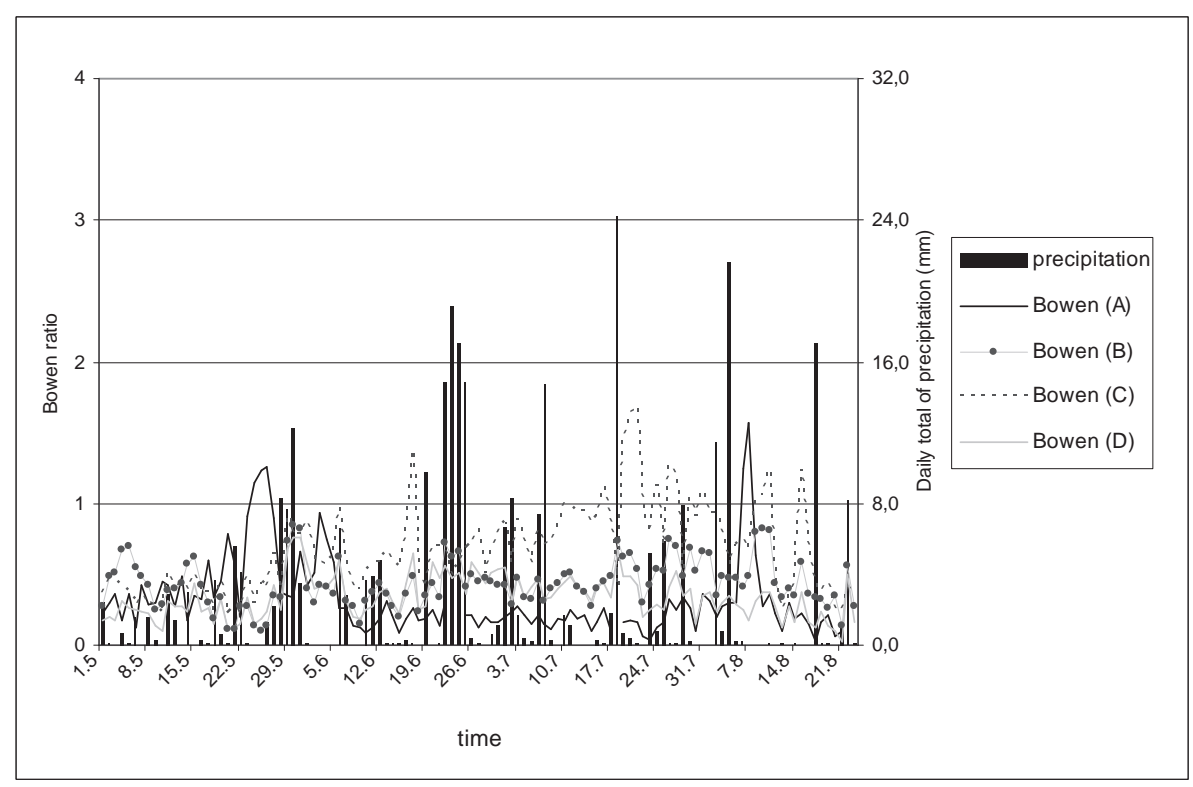

Figure 7. Average daily values of the Bowen ratio for the Dehtáře catchment, 2009 
by the highest ETa and the lowest Bowen ratio values. The daily averages of ETa at the station $\mathrm{C}$ on soils with the highest content of sand, shallow and stony (CMha), influenced by air mass coming from drying shallow CMha and deeper, but tile drained CMha were always the lowest ones. As a result, the average daily ETa was significantly lower and the corresponding $\beta$ significantly higher over coarser-textured soils (shallow CMha, C), namely (year-ETa $\left(\mathrm{mm} \mathrm{d}^{-1}\right)$ / $\beta$ ): $2004-1.75 / 1.66 ; 2006-2.44 / 0.93 ; 2009-2.60 / 0.81$, than over finer-textured soils (CMst and STha), namely: $2004-2.92 / 0.97 ; 2006-3.06 / 0.44 ; 2009-3.42 / 0.39$.

\begin{tabular}{|c|c|c|c|c|}
\hline \multirow[b]{2}{*}{ Subjects of comparison } & \multirow{2}{*}{$\begin{array}{l}\text { Compared } \\
\text { pair of } \\
\text { stations }\end{array}$} & \multirow[b]{2}{*}{ Year } & \multicolumn{2}{|l|}{$p$} \\
\hline & & & $\begin{array}{l}\text { From May } \\
\text { to mid- } \\
\text { July }\end{array}$ & $\begin{array}{l}\text { From mid- } \\
\text { July to mid- } \\
\text { August }\end{array}$ \\
\hline \multirow{3}{*}{$\begin{array}{l}\text { Soils affected by hydromorphism (STha, CMst) under different land } \\
\text { use (A - permanent grassland vs. B - field crops) and also the } \\
\text { discharge zone vs. the discharge/transient zone, both being tile- } \\
\text { drained }\end{array}$} & \multirow{3}{*}{$A \times B$} & 2004 & $0.03448^{*}$ & $0.00024^{*}$ \\
\hline & & 2006 & N.S. & N.S. \\
\hline & & 2009 & N.S. & N.S. \\
\hline \multirow{9}{*}{$\begin{array}{l}\text { Different Cambisol varieties in different terrain zones under the same } \\
\text { land use and different intensity of tile-drainage: } \\
\text { B (CMst/CMha, discharge/transient zone, tile-drained) } \\
\text { C (CMha, transient zone, partially tile-drained) } \\
\text { D (CMha, transient/recharge zone, not tile-drained) }\end{array}$} & \multirow{3}{*}{$B \times C$} & 2004 & $0.00096^{\star}$ & $0.03982^{*}$ \\
\hline & & 2006 & N.S. & $0.02649^{*}$ \\
\hline & & 2009 & $0.04805^{\star}$ & $0.00546^{\star}$ \\
\hline & \multirow{3}{*}{$B \times D$} & 2004 & N.S. & N.S. \\
\hline & & 2006 & N.S. & N.S. \\
\hline & & 2009 & N.S. & N.S. \\
\hline & \multirow{3}{*}{$C \times D$} & 2004 & $0.03808^{*}$ & N.S. \\
\hline & & 2006 & N.S. & N.S. \\
\hline & & 2009 & N.S. & $0.00011^{*}$ \\
\hline \multirow{6}{*}{$\begin{array}{l}\text { Permanent grass cover on Stagnosol, discharge zone, tile-drained (A) } \\
\text { vs. field crops on Haplic Cambisol, transient (C) or recharge/transient } \\
\begin{array}{ll}\text { (D) zone, partially tile-drained } & \text { (C) or not tile-drained (D) }\end{array}\end{array}$} & \multirow{3}{*}{$A \times C$} & 2004 & N.S. & $<10^{-5 *}$ \\
\hline & & 2006 & N.S. & N.S. \\
\hline & & 2009 & N.S. & $0.00004^{*}$ \\
\hline & \multirow{3}{*}{$A \times D$} & 2004 & N.S. & $<10^{-5 *}$ \\
\hline & & 2006 & N.S. & N.S. \\
\hline & & 2009 & N.S. & N.S. \\
\hline
\end{tabular}

* the null hypothesis rejected

N.S. = not significant

Table 5. The significance levels ( $p$ ) for paired t-tests comparing average daily ETa values 
With regard to the soil water regime and ETa, the CMst and STha of the station B with a drainage system and being in concentrated water flow acted similarly to the CMha of the station D without a drainage system (D), i.e. no differences were found between stations B and D.

Differences in ETa between stations C and D (i.e. higher values of the station D), both being at the interface shallow and deeper CMha, could be explained by the share of wind coming from drying shallow and tile drained CMha. Within valid ETa values, the station $C$ was influenced of $80-85 \%$ by the wind coming from drying shallow CMha and tile drained areas, while to the station D the wind went from shallow CMha only from $33-47 \%$. Thus the significance of prevailing wind direction in ETa determination in soil heterogeneous conditions was evident.

Under extremely dry conditions (period 2, 2004), there were significant differences between the station $A$ and the other stations, because of the dried-out soil profile under arable land (stations B to D), while the lowest part of the catchment around the station A was still relatively wet. The differences in terms of Bowen ratios (the average values between 10:00 and 18:00 of each day when $\mathrm{Rn}>70 \mathrm{~W} \mathrm{~m}^{-2}$ ) were also visible. The $\beta$ values pertaining to the stations B to D rose in July and August 2004 very sharply while those measured at A remained low (Fig. 5). Additionally, the soil water regime of the station A was markedly influenced by the reduction of ETa after grass cutting (i.e. after the above-ground biomass removal). Taken separately over the periods 1 and 2 as well as over the entire growing seasons in particular years, the stations $C$ and $D$ typically gave the highest Bowen ratios (Figs. 6, 7).

\subsection{Wet weather conditions}

In the period 1 the crop transpiration, a critical component of evapotranspiration, was in most cases not limited by the (non-existing) soil water deficit. The water supply to plants was sufficient and uninterrupted, while the crop stand was already fully developed. Under these conditions, both soil evaporation and plant transpiration were affected by weather factors in a similar way. The uplift of water through the plant tissues is markedly more efficient than the soil water upward movement during physical evaporation only [43]. After precipitation, the water that has infiltrated into the soil is mainly utilized for transpiration of the fully developed stand, that is, the soil physical properties have only a limited effect on its upward movement. Thus, the prevalence of the transpiration component of evapotranspiration acted as an equalizing factor on ETa from heterogeneous soil areas. The effect of physical properties of the soil was thereby masked. As a result, the daily ETa values were statistically the same across various soil types and crop species (a similar conclusion was made by [44]), except in the dry period of 2004. [45] arrived at similar conclusions, stating that the values of cumulative physical evaporation showed a more pronounced change with alterations in soil texture than did the values of cumulative transpiration. Figs. 3-4 and 6-7 support this conclusion by showing that, in the period 1, the differences in ETa and $\beta$ among individual weather stations were negligible.

\section{Conclusion}

Different soil physical properties of the catchment, interacting with the tile-drainage system effects, terrain relief, manifested themselves in corresponding daily evapotranspiration dif- 
ferences during the periods of limited transpiration, either at the onset of crop maturity and/or during the soil drought. The fine-textured soils in the discharge and discharge/transient zones, affected more by shallow groundwater table and shallow subsurface flow were marked in most cases by the highest ETa and the lowest Bowen ratio values. The daily averages of ETa referring to soils with the highest content of sand, shallow and stony, were always the lowest ones.

The transpiration of a green plant cover, which took up a major portion of the soil water storage through its root suction force and was not, in most cases, limited by the soil water deficit, acted as an equalizing factor of evapotranspiration from heterogeneous soil areas. The transpiration also mitigated the differences in evapotranspiration among different soils, even when these were carrying different crops. The vegetation canopy thus minimized runoff in any form and reduced the infiltration and the groundwater recharge in the recharge zones.

In addition to soil conditions, the results of ETa research were also connected with the method used (Bowen ratio method) which is dependent on air temperature and humidity coming over extensive plant cover from prevailing wind direction.

\section{Acknowledgements}

This study was supported by the grants from the Ministry of Agriculture of the CR within the research programmes MZE 0002704902-03-01, MZE 0002704902-01-02 and the project no. QH92034.

\section{Author details}

Renata Duffková*

Address all correspondence to: duffkova.renata@vumop.cz

Research Institute for Soil and Water Conservation, Praha, Czech Republic

\section{References}

[1] Monteith, J. L. Vegetation and the Atmosphere. Principles. London, New York, San Francisco: Academic Press; (1976). , 1

[2] Ward, A. D, \& Elliot, W. J. Editors. Environmental hydrology. Boca Raton, New York: Lewis Publishers; (1995). 
[3] Allen, R. G, Pereira, L. S, Raes, D, \& Smith, M. crop evapotranspiration, Guidelines for computing crop water requirements. FAO Irrigation and Drainage Paper 56. Rome: Food and Agriculture Organization of the United Nations; (1998).

[4] Dunn, S. M, \& Mackay, R. Spatial variation in evapotranspiration and the influence of land use on catchment hydrology. Journal of Hydrology (1995). , 171, 49-73.

[5] Serrano, S. E. Hydrology for Engineers, Geologists and Environmental Professionals. Kentucky: HydroScience Inc. Lexington; (1997).

[6] Mengelkamp, H. T, Warrach, K, \& Raschke, E. SEWAB- a parameterization of the Surface Energy and Water Balance for atmospheric and hydrologic models. Advances in Water Resources (1999). , 23, 165-175.

[7] Jhorar, R. K. Bastiaanssen, WGM., Feddes RA., Van Dam JC. Inversely estimating soil hydraulic functions using evapotranspiration fluxes. Journal of Hydrology (2002). , 258, 198-213.

[8] Brutsaert, W. Hydrology- an Introduction. Cambridge: Cambridge University Press; (2005).

[9] Luxmoore, R. J, \& Sharma, L. M. Evapotranspiration and soil heterogeneity. Agricultural Water Management (1984). , 8, 279-289.

[10] Bronstert, A, \& Plate, E. J. Modelling of runoff generation and soil moisture dynamics for hillslopes and micro-catchments. Journal of Hydrology (1997). , 198, 177-195.

[11] Popova, Z, \& Kercheva, M. CERES model application for increasing preparedness to climate variability in agricultural planning-risk analyses. Physics and Chemistry of the Earth (2005). , 30, 117-124.

[12] Doležal, F, \& Kvítek, T. The role of recharge zones, discharge zones, springs and tile drainage systems in peneplains of Central European highlands with regard to water quality generation processes. Physics and Chemistry of the Earth, Parts A/B/C (2004).

[13] Fucík, P, Kvítek, T, Lexa, M, Novák, P, \& Bílková, A. Assessing the Stream Water Quality Dynamics in Connection with Land Use in Agricultural Catchments of Different Scales. Soil \& Water Research (2008). , 3, 98-112.

[14] Kvítek, T, et al. Grassing of arable land with high infiltration hazard-a tool for reducing nitrate load in waters. Methodics of RISWC. Praha; (2007). in Czech)

[15] Lexa, M. The evaluation of nitrate concentratins of small streams in Želivka catchment and its analysis. Ph.D. thesis. Charles University, Faculty of Science, Praha; (2006). in Czech)

[16] Rychnovská, M, Balátová-tulácková, E, Úlehlová, B, \& Pelikán, J. Meadows ecology. Praha: Academia; (1985). in Czech) 
[17] Zheng, F. L. Huang ChH., Norton LD. Effects of Near-Surface Hydraulic Gradients on Nitrate and Phosphorus Losses in Surface Runoff. Journal of Environmental Quality (2004). , 33, 2174-2182.

[18] Barrett, M. E, \& Charbeneau, R. J. A parsimonious model for simulating flow in a karst aquifer. Journal of Hydrology (1997). , 196, 47-65.

[19] Minár, J, \& Evans, S. Elementary forms for land surface segmentation: The theoretical basis of terrain analysis and geomorphological mapping. Geomorphology (2008). , 95, 236-259.

[20] Demek, J, et al. Geography Lexicon of the Czech Socialist Republic- Mountains and Basins. Praha: Academia; (1987). in Czech)

[21] Tolasz, R, et al. Climate Atlas of Czechia. Praha-Olomouc: Czech Hydrometeorological Institute, Palacký University Olomouc, $1^{\text {st }}$ edition; (2007).

[22] World reference base for soil resources (2006). Rome: World Soil Resources Reports 103. Food and Agriculture Organization of the United Nations; 2006.

[23] USDA-NRSC Soil taxonomyAgricultural Handbook Second Edition; (1999). (436)

[24] Karous, M, \& Chalupník, T. Geophysical research of soil characteristics in a nonsaturated zone at the Dehtáře locality. Praha; (2006). in Czech)

[25] Karous, M, \& Chalupník, T. Geophysical research of soil characteristics in a nonsaturated zone at the Dehtáře locality phase (2007). Praha; 2007. (in Czech)

[26] Haken, D, \& Kvítek, T. Dynamics of the water regime in the drained meadow soil. Praha: Scientific works of the Institute of Agricultural Land Improvement (1982). in Czech), 1, 23-35.

[27] Haken, D, \& Kvítek, T. The effectiveness of full-scale reclamation of waterlogged meadow sites in the potato vegetation region. Collection of the Institute of Scientific and Technical Information for Agriculture. Meliorations (1984). in Czech), 2, 121-132.

[28] Monteith, J. L. Principles of Environmental Physics. London: Edward Arnold (Publishers) Limited; (1973).

[29] Heilman, J. L, \& Brittin, C. L. Fetch requirements for Bowen ratio measurements of latent and sensible heat fluxes. Agricultural and Forest Meteorology (1989). , 44, 261-273.

[30] Pauwels VRNSamson R. Comparison of different methods to measure and model actual evapotranspiration rates for a wet sloping grassland. Agricultural Water Management (2006). , 82, 1-24.

[31] Tattari, S, Ikonen, J. P, \& Sucksdorff, Y. A comparison of evapotranspiration above a barley field based on quality tested Bowen ratio data and Deardorff modelling. Journal of Hydrology (1995). , 170, 1-14. 
[32] Todd, R. W, Evett, S. R, \& Howell, T. A. The Bowen ratio-energy balance method for estimating latent heat flux of irrigated alfalfa evaluated in a semi-arid, advective environment. Agricultural Forest Meteorology (2000). , 103, 335-348.

[33] Grace, J. Plant-Atmosphere Relationships. London, New York: Chapman and Hall; (1983).

[34] Inman-bamber, N. G, \& Mc Glinchey, M. G. Crop coefficients and water-use estimates for sugarcane based on long-term Bowen ratio energy balance measurements. Field Crops Research (2003). , 83, 125-138.

[35] Perez, P. J, Castellvi, F, Ibanez, M, \& Rosell, J. I. Assessment of reliability of Bowen ratio method for partitioning fluxes. Agricultural and Forest Meteorology (1999). , 97, 141-150.

[36] Klika, J, Novák, V, \& Gregor, A. Manual of phytocenology, ecology, climatology and pedology. Praha: Publishing House of the Czechoslovak Academy of Sciences; (1954). in Czech)

[37] Kutílek, M. Water Management Pedology. Praha: Státní nakladatelství technické literatury; (1966). in Czech)

[38] ISO 11277(1998). Cor 1. Determination of particle size distribution in mineral soil material- Method by sieving and sedimentation; 2002.

[39] Yeh, G. T, \& Brutsaert, W. H. A solution for simultaneous turbulent heat and vapour transfer between a water surface and the atmosphere. Boundary-Layer Meteorology (1971). , 2, 64-82.

[40] Steduto, P, \& Hsiao, T. C. Maize canopies under two soil water regimes. I. Diurnal patterns of energy balance, carbon dioxide flux, and canopy conductance. Agricultural and Forest Meteorology (1998). , 89, 169-184.

[41] Salvucci, G. D, \& Entekhabi, D. Hillslope and climatic controls on hydrologic fluxes. Water Resources Research (1995). , 31, 1725-1739.

[42] Yokoo, Y, Sivapalan, M, \& Oki, T. Investigating the roles of climate seasonality and landscape characteristics on mean annual and monthly water balances. Journal of Hydrology (2008). , 357, 255-269.

[43] Novák, V. Water evaporation in nature and methods for its determination. Bratislava: VEDA. Publishing House of the Slovak Academy of Sciences; (1995). In Slovak)

[44] Mahmood, R, \& Hubbard, K. G. Simulating sensitivity of soil moisture and evapotranspiration under heterogeneous soils and land uses. Journal of Hydrology (2003). , 280, 72-90.

[45] Kozak, A. J, Ahuja, L. R, Ma, L, \& Green, T. R. Scaling and estimation of evaporation and transpiration of water across soil textures. Vadose Zone Journal (2005). , 4, 418-427. 